\title{
Oxygen stores and foraging behavior of two sympatric, planktivorous alcids
}

\author{
Kyle Hamish Elliott ${ }^{1, *}$, Akiko Shoji ${ }^{2}$, Kevin L. Campbell ${ }^{1}$, Anthony J. Gaston ${ }^{2,3}$ \\ ${ }^{1}$ Department of Biological Sciences, 190 Dysart Road, University of Manitoba, Winnipeg, Manitoba R3T 2N2, Canada \\ ${ }^{2}$ Department of Biology, University of Ottawa, 30 Marie Curie, University of Ottawa, Ottawa, Ontario K1N 6N5, Canada \\ ${ }^{3}$ Environment Canada, National Wildlife Research Centre, Carleton University, 1125 Colonel By Drive, Ottawa, \\ Ontario K1S 5B6, Canada
}

\begin{abstract}
Seabird species with overlapping diets commonly coexist at breeding colonies. For example, ancient murrelets Synthliboramphus antiquus and Cassin's auklets Ptychoramphus aleuticus are similar-sized small alcids that feed on krill and small fish. Little is known regarding their partitioning of aquatic resources, so we assessed the $\mathrm{O}_{2}$ stores and foraging behavior of sympatrically breeding populations of these species. The attachment of recorders ( 1 to $3 \%$ of body mass) caused substantial nest desertion, but we reduced these effects by only equipping experienced birds early in the day. Auklets and murrelets had 18 to $24 \%$ higher mass-specific $\mathrm{O}_{2}$ stores than slightly larger nondiving kittiwakes Rissa tridactyla. When compared to published values, blood hemoglobin content was higher, muscle $\mathrm{pH}$ buffering capacity was similar and muscle myoglobin content was lower for small divers than for larger non-phocid divers. The slightly higher $\mathrm{O}_{2}$ stores of Cassin's auklets was reflected in their aquatic behavior, as auklets dived longer than murrelets at any given dive depth. Moreover, chick-rearing auklets spent $31 \%$ more time underwater than incubating auklets and $50 \%$ more time underwater than incubating murrelets. In total, $45 \%$ of dives by chick-rearing auklets, $36 \%$ of dives by incubating auklets and $13 \%$ of dives by incubating murrelets exceeded their estimated aerobic dive limits. Murrelets primarily used V-shaped dives while auklets generally exhibited $\mathrm{W}$-shaped dive profiles with a protracted bottom phase. Thus the $\mathrm{O}_{2}$ stores and foraging behavior of the 2 sympatric seabirds differed.
\end{abstract}

KEY WORDS: Cassin's auklet $\cdot$ Ptychoramphus aleuticus $\cdot$ Ancient murrelet $\cdot$ Synthliboramphus antiquus $\cdot$ Reef Island $\cdot$ Haida Gwaii $\cdot$ Hemoglobin $\cdot$ Myoglobin Resale or republication not permitted without written consent of the publisher

\section{INTRODUCTION}

Maximum dive duration scales strongly with body mass, so that for fixed transit times small animals are limited to brief access to their prey and hence are under strong selection to increase time available for foraging underwater (Watanuki \& Burger 1999, Halsey et al. 2006). Small size also restricts the size of devices that can be used to monitor underwater behavior, and most of what is known about the at-sea behavior of small divers has been obtained from observations at the surface (Hunt et al. 1998). However, recent advances in the miniaturization of electronic recorders now permit detailed examinations of the free-ranging dive profiles of some of the smallest marine endo- therms, the planktivorous alcids (Harding et al. 2009). The planktivorous alcids (Alcidae) form an important component of North Pacific marine ecosystems, yet the behaviors by which they detect and procure prey underwater remain virtually unknown (Burger \& Powell 1990). Thus, although parameters measurable at the colony, such as reproductive success and survival, suggest a strong effect of ocean climate on the biology of North Pacific planktivorous alcids (Abraham \& Sydeman 2006, Hipfner 2008, Wolf et al. 2009), the physiological mechanisms that mediate between freeranging populations and their prey remain speculative. Our ability to understand the plasticity of planktivorous birds to oceanographic change and to interpret changes in demographic measures depends on a thor- 
ough understanding of the mechanisms that link zooplankton abundance to demography through foraging behavior. Unfortunately, little is known regarding the factors underlying the breath-hold capabilities or atsea behavior of these diminutive divers.

In terrestrial ecosystems, apparently similar sympatric species often actually occupy somewhat different niches (e.g. Grant \& Grant 2002). In marine ecosystems, some sympatric large-bodied animals (penguins and seals) possess differences in $\mathrm{O}_{2}$ stores and segregate based on dive depth, with one species feeding on high density prey at depth and another on low density prey nearer the surface (Trivelpiece et al. 1987, Mori \& Boyd 2004). Other sympatric large-bodied species show similar dive abilities but segregate based on foraging locations (Trivelpiece et al. 1987, Hull 1999) or timing of foraging activities (Bailleul et al. 2005, Luque et al. 2007). In contrast, the mechanisms underlying the partitioning of aquatic resources among sympatric populations of small seabirds remain unclear. Twenty species of alcids inhabit the North Pacific and surrounding waters, including 9 species that are primarily planktivorous and several more that are partially planktivorous. As planktivorous alcids are often sympatrically distributed and exploit similar prey items (Hunt et al. 1998), they present excellent model systems for examining how marine animals partition their niches.

Cassin's auklets Ptychoramphus aleuticus and ancient murrelets Synthliboramphus antiquus breed sympatrically in the Haida Gwaii archipelago off the Pacific coast of British Columbia. Stomach contents obtained from both species collected at-sea contained larval fish and Thysanoessa euphausiids; auklet stomachs also contained copepods, while murrelet stomachs also contained Euphausia pacifica (Sealy 1975, Vermeer et al. 1985). The 2 species represent examples of the 2 main planktivorous alcid clades: the auklets (single egg, long chick-rearing period at the colony, feet placed more anterior) and murrelets (2 eggs, chicks are precocial and leave the colony at 2 days of age, feet placed more posterior). To better understand the behavioral underpinnings of resource competition between these species, we initiated a study using timedepth-temperature recorders (TDTRs) to examine their flight durations and at-sea dive profiles. To identify physiological mechanisms accounting for underwater endurance and at-sea dive profiles, we also measured muscle myoglobin and buffering capacity, assayed blood hemoglobin and hematocrit and estimated total body $\mathrm{O}_{2}$ stores of both species. As these birds have body masses at the lower limit of those considered acceptable for available instruments, we also investigated the impact of the devices on desertion rates to provide guidelines for future research. The Gwaii
Haanas National Marine Conservation Area, adjacent to Reef Island, is currently in the planning phase. Thus knowledge of what depths and foraging radii auklets and murrelets utilize could be useful for selecting areas to protect that maximize benefit to these birds.

\section{MATERIALS AND METHODS}

Effect of instrumentation. All deployments occurred at Reef Island, Haida Gwaii $\left(52.93^{\circ} \mathrm{N}, 131.54^{\circ} \mathrm{W}\right)$. Birds were captured during the daytime either in nestboxes (most ancient murrelets) or in natural burrows (all Cassin's auklets and 2 murrelets) and instrumented with TDTRs. The only exceptions were chick-rearing auklets, 3 of which were captured using mist nets during nighttime, and 8 incubating ancient murrelets also obtained during nighttime using nets that knocked them to the ground (knock-down nets), at which time they were immediately captured by hand. Upon recapture, TDTRs were removed, birds were weighed to the nearest gram and a small blood sample was taken on protein-saver paper for sexing using PCR. Handling time was $<3$ min for both capture and recapture protocols.

We attached devices 27 April to 20 May 2008 and 28 April to 12 May 2009. We attached cylindrical Lotek 1100LTD TDTRs (sampling interval $=3 \mathrm{~s}$, memory $=$ $128 \mathrm{kB}$, mass $=5 \mathrm{~g}$, diameter $=1 \mathrm{~cm}$, length $=3.3 \mathrm{~cm}$, accuracy $\pm 2 \mathrm{~m}$; Elliott \& Gaston 2009) to 10 incubating murrelets and 6 auklets in 2008 and 5 murrelets and 5 incubating and 3 chick-rearing auklets in 2009. The devices were attached with duct tape to a metal band, which was then attached to the foot with the pressure sensor facing posterior. In 2009, we also attached 1500LAT TDTRs (sampling interval $=1 \mathrm{~s}$ for auklets and either 4 or $12 \mathrm{~s}$-with $1 \mathrm{~s}$ sampling when depth was $>2 \mathrm{~m}$-for murrelets; memory $=512 \mathrm{kB}$, mass $=$ $2.8 \mathrm{~g}$, diameter $=0.5 \mathrm{~cm}$, length $=3.3 \mathrm{~cm}$, resolution \pm $0.25 \mathrm{~m}$ ) to 8 incubating murrelets, 2 incubating auklets and 1 chick-rearing auklet. In addition, we deployed 18 maximum depth gauges (MDGs; $80 \mathrm{~mm}$ Tygon tubing powdered with icing sugar so that maximum pressure could be deduced from where the icing sugar was washed away by sea water following Elliott \& Gaston 2009) on 18 murrelets (10 in natural burrows in the daytime and 8 in knock-down nets at night) and 5 auklets (all in natural burrows) in 2008.

In 2008 , to compare various potential treatments, we also attached dummy (candle wax and lead shot) devices of different sizes (2.8 and $5 \mathrm{~g}$ ) and design (back-mounted, $\mathrm{N}=6$; leg-mounted, $\mathrm{N}=5$; legmounted attached by cable tie without removing the bird from the burrow, $\mathrm{N}=5$ ) to ancient murrelets ( 5 for each treatment) in natural burrows. 
Physiological parameters and $\mathbf{O}_{2}$ stores. In 2008, blood samples were taken from 10 non-breeding (lacking a brood patch) ancient murrelets captured at night and 10 incubating auklets ( 5 captured during the day, 5 at night). Samples were obtained from the brachial vein using a 27 gauge needle and $1 \mathrm{ml}$ syringe, and transferred into heparinized microhematocrit tubes. Hematocrits were measured in duplicate following a 5 min spin. The remaining capillary tubes were emptied into cryovials and immediately frozen in liquid nitrogen until return to the laboratory, where hemoglobin concentration was measured using the cyanmethemoglobin method (Sigma diagnostics total hemoglobin procedure no. 525, which states that blood frozen up to $1 \mathrm{yr}$ is suitable for analyses; a $20 \mu \mathrm{l}$ blood sample from each individual was also placed in $5 \mathrm{ml}$ of Drabkin's solution at the time of collection and frozen; both procedures gave similar results). Standards were prepared from lyophilized human hemoglobin (Sigma Hemoglobin Standard no. 525-18). Samples were diluted to obtain values within the standard curve, and the hemoglobin concentrations calculated by dividing the measured value by the percent dilution. We did not filter or centrifuge the samples as no turbidity was observed, probably because the birds were captured at the colony and had not eaten recently. Hematocrit samples were also obtained from 10 non-breeding and 10 breeding ancient murrelets in 2009.

In 2008, we also euthanized 5 non-breeding murrelets and 5 breeding auklets by cervical dislocation following blood collection. The heart, right leg muscle (sartorius and gastrocnemius) and a portion of the right breast muscle (pectoralis and supracoracoideus) were immediately dissected free, weighed to the nearest $0.1 \mathrm{~g}$ and placed in $\mathrm{a}-70^{\circ} \mathrm{C}$ nitrogen shipper together with the remaining carcass. Non-muscle portions of the bird (e.g. alimentary tract, skin, brain) were removed and the carcass was re-weighed and placed in a heated solution containing the enzyme papain, Bio-Ad detergent and EDTA for $48 \mathrm{~h}$ (MacArthur et al. 2001). The mass difference following this treatment was ascribed to muscle and hence added to the breast, leg and heart muscle weights to obtain a total estimate of body muscle mass. For comparative purposes, blood and muscle samples were also obtained from 5 blacklegged kittiwakes Rissa tridactyla and 5 thick-billed murres Uria lomvia collected at Prince Leopold Island in 2008. Heart, leg and breast muscle subsamples from each of the 4 avian species were analyzed for myoglobin concentration using the methods of Reynafarje (1963). Briefly, we homogenized $\sim 0.5 \mathrm{~g}$ of muscle in a low ionic strength phosphate buffer $(19.25 \mathrm{ml}$ buffer per $1 \mathrm{~g}$ of wet tissue) using a mechanical tissue grinder submerged in an ice bath (MacArthur et al. 2001). The homogenate was then centrifuged at $11000 \times g$ for
$1.5 \mathrm{~h}$ at $5^{\circ} \mathrm{C}$, and $4 \mathrm{ml}$ of supernatant was transferred to a custom-built glass vial through which carbon monoxide was bubbled for $8 \mathrm{~min}$. Excess sodium dithionite was added and carbon monoxide bubbled for an additional 2 min to assure complete reduction. The supernatant was then placed in a cuvette and absorption was read at 538 and $568 \mathrm{~nm}$ and converted to myoglobin concentration following Reynafarje (1963).

Total $\mathrm{O}_{2}$ stores $\left(T_{\mathrm{O}_{2}}\right)$ for each individual was estimated as:

$$
T_{\mathrm{O}_{2}}=0.9 \times 0.176 \times 0.1608 M^{0.91}+1.34 M_{\mathrm{b}} M_{\mathrm{m}}+B_{\mathrm{O}_{2}}
$$

where the first term is the respiratory $\mathrm{O}_{2}$ stores of a bird of mass $M(\mathrm{~kg})$, assuming respiratory volume followed the allometric relationship determined by Lasiewki \& Calder (1971), that $17.6 \%$ of lung volume was $\mathrm{O}_{2}$ and $90 \%$ of lung $\mathrm{O}_{2}$ stores were usable (Croll et al. 1992, Knower Stockard et al. 2005). The second term is the muscle $\mathrm{O}_{2}$ stores, where $M_{\mathrm{m}}$ is body muscle mass $(\mathrm{g})$, assuming that each gram of myoglobin can bind $1.34 \mathrm{ml} \mathrm{O}_{2}$ (Ponganis et al. 1997). We assumed that all muscle that was not heart or breast had a myoglobin concentration $\left(M_{\mathrm{b}}\right)$ similar to the leg. The third term, blood $\mathrm{O}_{2}$ stores $B_{\mathrm{O}_{2}}$ was estimated as:

$$
B_{\mathrm{O}_{2}}=0.96 \times 1.34(0.95 \times 0.3+0.7 \times 0.7) H \times 0.123 M
$$

Blood hemoglobin content $\left(H, \mathrm{~g} \mathrm{dl}^{-1}\right)$ was measured directly. We assumed blood volume was $12.3 \%$ of body mass in $\mathrm{g}$ (as determined for murres; Croll et al. 1992), the $\mathrm{O}_{2}$ binding capacity of hemoglobin was $1.34 \mathrm{ml} \mathrm{g}^{-1}$ pigment (Tamburrini et al. 1994), $30 \%$ of the blood was arterial at $95 \% \mathrm{O}_{2}$ saturation and $70 \%$ was venous at $70 \%$ saturation, and $96 \%$ of $\mathrm{O}_{2}$ was usable (Croll et al. 1992).

The buffering capacity of pectoralis muscle, defined as the amount of base required to raise the $\mathrm{pH}$ of $1 \mathrm{~g}$ of wet muscle from 6 to 7 , was determined following the procedure of Castellini \& Somero (1981). This entailed homogenizing $\sim 0.5 \mathrm{~g}$ muscle subsamples in $0.9 \mathrm{M}$ $\mathrm{NaCl}$, followed by titration at $37^{\circ} \mathrm{C}$ with a $0.2 \mathrm{M} \mathrm{NaOH}$ solution using an Accumet $\mathrm{AB}$ 15/15+ pH meter equipped with an AccuTupH sensing electrode (Fisher Scientific).

We also compiled data for hematocrit, hemoglobin content, myoglobin concentration and buffering capacity in birds and mammals from the literature and correlated these values with body mass. Separate correlations were conducted for terrestrial and aquatic and/or semi-aquatic animals. Terrestrial, aquatic (freshwater diving) and marine (marine diving) animals were analyzed separately to assess whether any of the above traits differed among these 3 groups. All correlations were completed on log-transformed values. Unless otherwise noted, all values are presented as means $\pm 1 \mathrm{SE}$. 
Foraging behavior. Due to device uncertainty, only depths $>2 \mathrm{~m}$ were considered dives. A customdesigned Visual Basic macro corrected for passive electronic drift (based on the last 10 consecutive, identical pressure values before the dive), converted the pressure linearly into depth $(1.00 \mathrm{~m}=1.00 \mathrm{dbar}=$ $1.41 \mathrm{psi}$ ) and was used to calculate ascent and descent rates, maximum depth, dive duration and surface pause duration.

We defined surface pauses as anticipatory if they correlated better with the following dive duration and reactive if they correlated better with the previous dive duration, with the former representing bout structure where birds anticipate subsequent dive durations and required $\mathrm{O}_{2}$ stores and the latter representing bout structure where birds react to previous dive durations and lactate build-up (Jodice \& Collopy 1999, Elliott et al. 2007, 2008b). We divided dives into bouts using the sequential differences method and a 2-process exponential model, where one process is the random distribution of events, or dives, within a bout, and the other process is the random distribution of events, or bouts (criterion: 70 s surface interval differences for murrelets, 90 s for auklets; Mori et al. 2001). A 1-process exponential model would mean that dives were randomly distributed across time and not organized into bouts. The temperature log was used to classify the time devoted to the following activities: (1) flying (temperature variable and medium); (2) resting on the surface (temperature constant and low, or constant and very high when the bird tucked its foot into its plumage); and (3) at the colony (high temperature, low pressure). We also obtained regurgitations from 4 chick-rearing auklets captured at night.

We estimated maximum possible foraging radii, assuming an estimated flight speed of $55 \mathrm{~km} \mathrm{~h}^{-1}$ (Elliott et al. 2004). When flying is broken into bouts the maximum distance traveled from the colony is generally less than estimated assuming all flights are directed away from or towards the colony. In that case, the actual feeding area is probably much closer to the colony than the maximum distance estimated from total flight time (Thaxter et al. 2009, Elliott et al. 2009a), so our values are likely overestimates.

\section{RESULTS}

\section{Effect of instrumentation}

In 2008, 7 of 10 ancient murrelets and 5 of 6 incubating Cassin's auklets equipped with the $5 \mathrm{~g}$ TDTRs deserted (Table 1). Murrelets equipped with MDGs in natural burrows during the daytime (11 of 15) or using knockdown nets in the nighttime (8 of 9) showed a high rate of abandonment, though it is possible that birds initially caught in knockdown nets may have avoided the nets during subsequent nights rather than deserting. Auklets equipped with MDGs also had low return rates (2 of 3 incubating birds and 0 of 1 chickrearing bird). Excluding MDGs, we recaptured 9 of 26 murrelets (35\%) and 1 of 6 incubating auklets (17\%) in 2008. In contrast, seabirds equipped with 2.8 or $5 \mathrm{~g}$ TDTRs in 2009 had much higher recapture rates (12 of 13 or $92 \%$ of murrelets, 7 of 8 or $88 \%$ of incubating auklets, and 4 of 4 or $100 \%$ of chick-rearing auklets). Overall recapture rate, excluding MDGs, in 2009 (23 of 25) was higher than that in 2008 (10 of 32; Fisher's exact test, $\mathrm{p}<0.00001)$.

\section{Physiological parameters, $\mathrm{O}_{2}$ stores and aerobic dive limits}

Auklets had higher hematocrit $\left(t_{19}=2.45, \mathrm{p}=0.02\right)$, myoglobin concentration $\left(t_{9}=2.53, \mathrm{p}=0.03\right.$ ) and muscle buffering capacity $\left(t_{9}=3.85, \mathrm{p}=0.004\right)$ than murrelets, but similar hemoglobin concentration $\left(t_{9}=1.83\right.$, $\mathrm{p}=0.09$ ). In total, auklets possessed $5 \%$ higher massspecific $\mathrm{O}_{2}$ stores than murrelets, suggesting somewhat greater specialization for longer dive durations. Auklets had $24 \%$ and murrelets $18 \%$ higher $\mathrm{O}_{2}$ stores per gram of body mass than the slightly larger nondiving kittiwake (Table 2). The slightly higher $\mathrm{O}_{2}$ stores (relative to body mass) in auklets are unlikely to be due to the murrelets being non-breeders and the auklets being breeders, as hematocrit values were similar in non-breeding and breeding murrelets (Table 2). This is despite the fact that breeders spent 1 to $3 \mathrm{~d}$ in the burrow prior to sampling, presumably resulting in some dehydration.

\section{Foraging behavior}

We obtained free-ranging flight and dive data on 12 incubating ancient murrelets ( 2 additional birds returned, but logs were corrupted or data otherwise lost and we obtained data from one bird in both years) and 8 incubating and 4 chick-rearing Cassin's auklets (Table 3). We also retrieved 4 of 10 MDGs deployed on murrelets at natural burrows and 1 of 8 MDGs deployed using knockdown nets, and 2 of 4 MDGs deployed on auklets.

Auklets dove for longer than murrelets, while murrelets dove slightly deeper, meaning that auklets remain submerged for $60 \%$ longer than murrelets at any given dive depth (depth: Kruskal-Wallis $\chi^{2}=243.2$, df $=2$, $\mathrm{p}<0.00001$; duration: $\chi^{2}=1126.2$, df $=2, \mathrm{p}<0.00001$ ) (Fig. 1, Table 2). There was no difference in dive depth 
Table 1. Device effects on alcid mass loss, provisioning rates and recapture rates. F: females only; M: males only. Device mass was measured as \% body mass; S: device was sutured; I: device was surgically implanted. Also shown are adult body mass loss during deployment (or relative to control post-deployment); provisioning rate (feeds or trips for murres and razorbills; chick growth rate for auklets and puffins) relative to control (parentheses: chick relative fledging success); and recapture or non-abandonment rates of equipped birds excluding birds losing devices (where available, apparent annual survival is shown in parentheses followed by annual survival for control birds; battery cycle is shown for one study that suggested this was an important parameter, Hatch et al. 2000)

\begin{tabular}{|c|c|c|c|c|c|}
\hline Species & Device mass & $\begin{array}{l}\text { Body mass } \\
\text { loss }(\%)\end{array}$ & $\begin{array}{l}\text { Provisioning } \\
\quad \text { rate }(\%)\end{array}$ & Recapture rate $(\%)$ & Source \\
\hline \multicolumn{6}{|l|}{ Probable non-breeding } \\
\hline Xantus' murrelet & $1.8 \mathrm{~S}$ & & & $(4.5 ; 6.6)$ & Newman et al. (1999) \\
\hline \multicolumn{6}{|l|}{ Incubating } \\
\hline \multirow[t]{4}{*}{ Ancient murrelet } & 2.5 & & & $50\left(\operatorname{leg}_{1} \mathrm{~N}=20\right)$ & \\
\hline & & & & $33($ back, $\mathrm{N}=6)$ & \\
\hline & 1.3 & & & $\begin{array}{l}40\left(\operatorname{leg}, \text { in burrow }{ }^{\mathrm{a}}, \mathrm{N}=5\right) \\
88(\mathrm{~N}=9)\end{array}$ & $\begin{array}{l}\text { Present study } \\
\text { Present study }\end{array}$ \\
\hline & 1 & & & $\begin{array}{c}88(N=9) \\
88(23 ; 77, N=17)\end{array}$ & $\begin{array}{l}\text { Present study } \\
\text { Present study }\end{array}$ \\
\hline \multirow[t]{3}{*}{ Cassin's auklet } & 2.5 & & & $42(\mathrm{~N}=12)$ & Present study \\
\hline & 1.3 & & & $100(\mathrm{~N}=2)$ & Present study \\
\hline & 1.7 & & & 42 & Ackerman et al. (2004) \\
\hline Common murre & 0.7 & & & 0 & Wanless et al. (1985) \\
\hline Marbled murrelet & $5 \mathrm{I}, \mathrm{S}$ & & & $\begin{array}{l}\text { (harness/suture/ } \\
\text { surgery: 0; glue: 78) }\end{array}$ & Quinlan \& Hughes (1992) \\
\hline \multicolumn{6}{|c|}{ Incubation/chick-rearing unspecified } \\
\hline Common murre & $3.9 \mathrm{I}$ & & $(-100)$ & $\begin{array}{c}\text { (50; short cycle battery) } \\
\text { (53-73; long cycle battery) }\end{array}$ & $\begin{array}{l}\text { Meyers et al. (1998), } \\
\text { Hatch et al. (2000) }\end{array}$ \\
\hline Dovekie & 3.3 & -1.8 & & 63 & Harding et al. (2009) \\
\hline Thick-billed murre & $3.9 \mathrm{I}$ & & $(-100)$ & $\begin{array}{l}\text { ( } 0 \text {; short cycle battery) } \\
\text { (57; long cycle battery) }\end{array}$ & $\begin{array}{l}\text { Meyers et al. (1998), } \\
\text { Hatch et al. (2000) }\end{array}$ \\
\hline Tufted puffin & $4.9 \mathrm{I}$ & & & $\begin{array}{l}\text { ( } 0 \text {; short cycle battery) } \\
\text { (50; long cycle battery) }\end{array}$ & $\begin{array}{l}\text { Meyers et al. (1998), } \\
\text { Hatch et al. (2000) }\end{array}$ \\
\hline \multicolumn{6}{|l|}{ Chick-rearing } \\
\hline \multirow[t]{3}{*}{ Cassin's auklet } & $1.3-2.5$ & & & $100(\mathrm{~N}=4)$ & Present study \\
\hline & 1.7 & & $-44(-33)$ & 100 & Ackerman et al. (2004) \\
\hline & 1.3 & & & 100 & N. Karnovsky pers. comm \\
\hline \multirow[t]{5}{*}{ Common murre } & 0.7 & & -61 & $87(98)$ & Hamel et al. (2004) \\
\hline & 0.7 & & -30 & 100 & Wanless et al. (1988) \\
\hline & 0.7 & & & 100 & Wanless et al. (1985) \\
\hline & 0.5 & & & 60 & Hedd et al. (2009) \\
\hline & 2.7 & -3.2 & -33 & 100 & Tremblay et al. (2003) \\
\hline \multirow[t]{2}{*}{ Razorbill } & 1.2 & & -1 & 100 & Wanless et al. (1988) \\
\hline & 3.2 & -2.6 & & 93 & Dall'Antonia et al. (2001) \\
\hline \multirow[t]{4}{*}{ Thick-billed murre } & 0.5 & -1.0 & +16 & $100(91 ; 92)$ & Elliott et al. (2008a) \\
\hline & 1.5 & $-5-10$ & -64 & 100 & Watanuki et al. (2001) \\
\hline & 1.7 & -0.7 & $(-22)$ & 67 & Takahashi et al. (2008) \\
\hline & 2.9 & -3.7 & -43 & 100 & Elliott et al. (2008a) \\
\hline$(\mathrm{F})$ & 2.7 & -2.9 & $-64(0)$ & $100(85 ; 96)$ & Paredes et al. (2005) \\
\hline \multirow[t]{3}{*}{ (M) } & 2.4 & -2.8 & $-67(0)$ & $100(80 ; 96)$ & Paredes et al. (2005) \\
\hline & 3.0 & -1.0 & & 100 & Falk et al. (2002) \\
\hline & 3.3 & -1.6 & & 100 & Croll et al. (1992) \\
\hline Tufted puffin & 1.2 & & $(-61)$ & 92 & Whidden et al. (2007) \\
\hline
\end{tabular}

and duration between incubating and chick-rearing auklets (Mann-Whitney $U=1298633, \mathrm{n}_{1}=1447, \mathrm{n}_{2}=$ 2007, $\mathrm{p}=0.51$ ), but chick-rearing auklets dove more often (362 \pm 10 dives $\mathrm{d}^{-1}$, Table 3$)$ than incubating auklets $\left(276 \pm 31\right.$ dives $\left.\mathrm{d}^{-1} ; t_{10}=2.48, \mathrm{p}=0.03\right)$, as did incubating murrelets $\left(387 \pm 51\right.$ dives $\left.\mathrm{d}^{-1} ; t_{10}=2.42, \mathrm{p}=0.04\right)$. Thus chick-rearing auklets spent $31 \%$ more time underwater than incubating auklets and $50 \%$ more time underwater than incubating murrelets (incubating auklets thus spent $15 \%$ more time underwater than incubating murrelets). Surface pauses tended to be anticipatory rather than reactive ( $\triangle$ Akaike's information criterion $[\mathrm{AIC}]=104.3)$, and tended to correlate better with subsequent dive duration than with depth $(\triangle \mathrm{AIC}=$ 493.9). Incubating auklets had $5.4 \mathrm{~s}$ shorter surface pauses than incubating murrelets for a given dive dura- 
tion (residual surface pause on dive duration, $t_{8182}=$ 44.6, $\mathrm{p}<0.00001$ ), while chick-rearing auklets had $5.4 \mathrm{~s}$ shorter surface pauses than incubating auklets for a given dive duration $\left(t_{2429}=28.7, \mathrm{p}<0.00001\right)$ (Fig. 1).

The maximum foraging radius, given the total time spent flying, was $66 \mathrm{~km}$ (198 km for $3 \mathrm{~d}$ trips) for murrelets and $53 \mathrm{~km}$ for auklets (Table 4).

Murrelets showed higher transit rates than auklets (paired $t_{19}=7.15, \mathrm{p}<0.0001$ when paired across bins) (Fig. 2), and exhibited V-shaped dives rather than the W-shaped dives favored by auklets (Fig. 3). Thus auklets presumably searched for prey through the water column (low transit rates, higher within-bout variation in dive depth) and likely consumed multiple prey items at different depths (wiggle dives). This contrasts sharply with the murrelet strategy, which entailed rapid dives to a defined depth ( 9 m). Both species showed a 1-process model for sequential differences in depth, suggesting no bout structure in dive depth, but a 2-process model for surface pause intervals, suggesting that surface intervals provided bout structure (Fig. 1). Neither species dove at night, with diving starting $1 \mathrm{~h}$ before sunrise and ending $1 \mathrm{~h}$ after sunset (Fig. 4). Auklets provisioning with fish tended to have slightly deeper $($ mean $=3.1 \mathrm{~m}$; Table 2), V-shaped dives, while those provisioning with krill tended to have wiggle dives (Fig. 1). Dive depth (but not frequency) increased with tide height for murrelets (depth: $t_{199}=4.176, \mathrm{p}<0.0001$; frequency: $t_{199}=0.37$, $\mathrm{p}=0.71$; frequency: $\left.t_{199}=1.99, \mathrm{p}=0.05\right)$.

\section{Diet}

Two auklets regurgitated red krill Thysanoessa spinifera and 2 auklets regurgitated fish matter.

\section{DISCUSSION}

\section{Effect of instrumentation}

The 2009 recapture rates were comparable to those obtained from murrelets equipped with $1 \mathrm{~g}$ radio transmitters (with similar rates for birds with and without antennae; Table 1). Differences between the 2 years included: placement of TDTRs in the evening to maximize recording time in 2008 versus in the morning in 2009; and checking the box each day for murrelets after Day 2 of attachment in 2008 versus waiting $5 \mathrm{~d}$ before checking nest boxes to see if the banded bird was present or, alternatively, attaching a $1 \mathrm{~g}$ radio transmitter to the other leg so we could tell remotely if the bird was present.

The main factor affecting probability of abandonment in murrelets was whether the bird had been previously banded. In 2009, all except 4 recaptured TDTR-equipped birds (1 of which abandoned) were banded in 1984-2007, as were all but 1 (which abandoned) of the radio-equipped birds. Previously banded birds may be less likely to abandon because: (1) they tend to be older and less likely to sacrifice current reproduction for future survival; (2) they have been

Table 2. Oxygen storage parameters for 4 charadriiform birds ( $\mathrm{N}=5$ for muscle parameters; $\mathrm{N}=10$ for blood parameters). Murrelets were non-breeders, and the remaining birds were breeders. Values are given as means $\pm 1 \mathrm{SE}$

\begin{tabular}{|c|c|c|c|c|}
\hline Parameter & $\begin{array}{l}\text { Cassin's auklet } \\
\text { (small diver) }\end{array}$ & $\begin{array}{l}\text { Ancient murrelet } \\
\text { (small diver) }\end{array}$ & $\begin{array}{l}\text { Thick-billed murre } \\
\text { (large diver) }\end{array}$ & $\begin{array}{l}\text { Black-legged kittiwake } \\
\text { (small non-diver) }\end{array}$ \\
\hline Mass (g) & $171 \pm 2$ & $197 \pm 7$ & 980 & $359 \pm 6$ \\
\hline Usable respiratory $\mathrm{O}_{2}$ stores $\left(\mathrm{ml} \mathrm{kg}^{-1}\right)$ & 30.1 & 29.3 & 25.1 & 28.4 \\
\hline Hematocrit & $53 \pm 1$ & $51 \pm 1^{\mathrm{a}}$ & $48 \pm 1^{\mathrm{a}}$ & $44 \pm 2$ \\
\hline Hemoglobin content $\left(\mathrm{g} \mathrm{dl}^{-1}\right)$ & $20.7 \pm 0.6$ & $19.6 \pm 0.9$ & $18.1 \pm 1.0$ & $15.8 \pm 1.0$ \\
\hline Blood volume (ml) & $21 \pm 2$ & $24 \pm 2$ & $121 \pm 9$ & $44 \pm 4$ \\
\hline Usable blood $\mathrm{O}_{2}$ stores $\left(\mathrm{ml} \mathrm{kg}^{-1}\right)$ & $26.9 \pm 1.8$ & $25.9 \pm 2.0$ & $23.5 \pm 2.0$ & $20.9 \pm 1.9$ \\
\hline Myoglobin concentration - breast $\left(\mathrm{g} \mathrm{kg}^{-1}\right)$ & $10.6 \pm 0.3$ & $10.0 \pm 0.2$ & $13.5 \pm 2.4^{\mathrm{b}}$ & $4.2 \pm 0.5$ \\
\hline Myoglobin concentration - leg $\left(\mathrm{g} \mathrm{kg}^{-1}\right)$ & $8.0 \pm 0.4$ & $9.4 \pm 0.5$ & & \\
\hline Myoglobin concentration - heart $\left(\mathrm{g} \mathrm{kg}^{-1}\right)$ & $6.3 \pm 0.3$ & $6.1 \pm 0.9$ & $6.3 \pm 0.5$ & $5.9 \pm 0.7$ \\
\hline Right Pectoralis mass (g) & $11.2 \pm 0.3$ & $12.5 \pm 0.3$ & $71 \pm 4$ & $24 \pm 1$ \\
\hline Right Supracoracoideus mass (g) & $3.4 \pm 0.7$ & $3.4 \pm 0.2$ & $23 \pm 2$ & $2.5 \pm 0.6$ \\
\hline Right leg and pelvic muscle mass ( $g$ ) & $3.9 \pm 0.2$ & $4.0 \pm 0.2$ & & \\
\hline Heart mass (g) & $1.8 \pm 0.1$ & $1.9 \pm 0.1$ & $9.4 \pm 0.6$ & $4.7 \pm 0.1$ \\
\hline Total wet muscle mass $(\mathrm{g})$ & $47 \pm 1$ & $52 \pm 1$ & $298 \pm 10$ & $80 \pm 2$ \\
\hline Muscle $\mathrm{O}_{2}$ stores $\left(\mathrm{ml} \mathrm{kg}^{-1}\right)$ & $3.6 \pm 0.4$ & $3.4 \pm 0.4$ & $2.8 \pm 0.4$ & $1.3 \pm 0.1$ \\
\hline Total usable $\mathrm{O}_{2}$ stores $\left(\mathrm{ml} \mathrm{kg}^{-1}\right)$ & $61 \pm 2$ & $60 \pm 3$ & $51 \pm 2$ & $50 \pm 2$ \\
\hline Total usable $\mathrm{O}_{2}$ stores (ml) & $10.4 \pm 0.4$ & $11.8 \pm 0.5$ & $50.0 \pm 2.2$ & $18.0 \pm 0.8$ \\
\hline Buffering capacity (slyke) & $72 \pm 2$ & $64 \pm 2$ & $75 \pm 3$ & $52 \pm 4$ \\
\hline
\end{tabular}


Table 3. Synthliboramphus antiquus and Ptychoramphus aleuticus. Dive parameters $( \pm \mathrm{SD})$ for ancient murrelets and Cassin's auklets equipped with $5 \mathrm{~g} \mathrm{(5)}$ and $2.8 \mathrm{~g}$ (3) temperature-depth-time recorders (TDTRs). The last 4 birds were chick-rearing and regurgitated either euphausiids (E) or fish (F). F: female; M: male. Individual dive depths and durations for murrelets and auklets are available in Tables $\mathrm{S} 1$ and $\mathrm{S} 2$, respectively

\begin{tabular}{|c|c|c|c|c|c|c|c|c|c|c|}
\hline Species & Sex & Bird ID & TDTR & Year & $\begin{array}{l}\text { Mass } \\
(\mathrm{g})\end{array}$ & $\begin{array}{c}\text { No. dives } \\
\left(\mathrm{d}^{-1}\right)\end{array}$ & $\begin{array}{l}\text { Max } \\
\text { depth } \\
\text { (m) }\end{array}$ & $\begin{array}{l}\text { Average } \\
\text { depth } \\
\text { (m) }\end{array}$ & $\begin{array}{c}\text { Max } \\
\text { duration } \\
\text { (s) }\end{array}$ & $\begin{array}{l}\text { Average } \\
\text { duration } \\
\text { (s) }\end{array}$ \\
\hline \multirow{13}{*}{ Ancient murrelet } & $\mathrm{F}$ & 01047 & 5 & 2008 & 206 & 256 & 32.1 & $14.7 \pm 7.8$ & 69.5 & $39.6 \pm 16.9$ \\
\hline & $\mathrm{F}$ & 01047 & 3 & 2009 & nd & 654 & 20.5 & $6.2 \pm 3.3$ & 55.9 & $16.3 \pm 10.6$ \\
\hline & $\mathrm{M}$ & DN2 & 5 & 2008 & 200 & 758 & 36.8 & $11.0 \pm 5.2$ & 69.5 & $29.8 \pm 11.2$ \\
\hline & & 90460 & 5 & 2008 & 199 & 367 & 19.4 & $8.3 \pm 4.1$ & 50.1 & $22.5 \pm 9.7$ \\
\hline & $\mathrm{M}$ & 01002 & 5 & 2009 & nd & 263 & 26.7 & $12.0 \pm 7.3$ & 68.1 & $34.8 \pm 18.3$ \\
\hline & $\mathrm{F}$ & 56514 & 5 & 2009 & nd & 208 & 23.3 & $13.6 \pm 5.6$ & 64.7 & $39.6 \pm 12.6$ \\
\hline & $\mathrm{M}$ & 90531 & 5 & 2009 & 195 & 395 & 24.9 & $8.2 \pm 5.5$ & 64.3 & $23.3 \pm 13.6$ \\
\hline & $\mathrm{M}$ & 01067 & 3 & 2009 & 209 & 207 & 21.0 & $9.1 \pm 3.8$ & 65.7 & $26.8 \pm 12.2$ \\
\hline & $\mathrm{F}$ & 90460 & 3 & 2009 & 209 & 460 & 25.8 & $9.2 \pm 4.2$ & 65.4 & $18.3 \pm 13.1$ \\
\hline & & 90527 & 3 & 2009 & 198 & 427 & 25.3 & $6.7 \pm 4.1$ & 64.7 & $19.3 \pm 13.6$ \\
\hline & F & 53431 & 3 & 2009 & 215 & 285 & 15.0 & $5.8 \pm 2.0$ & 45.6 & $14.3 \pm 6.6$ \\
\hline & $\mathrm{M}$ & 53433 & 3 & 2009 & 202 & 414 & 25.8 & $9.7 \pm 5.4$ & 63.5 & $25.0 \pm 14.1$ \\
\hline & & 01004 & 5 & 2009 & 198 & 436 & 20.6 & $7.3 \pm 3.5$ & 62.9 & $22.5 \pm 10.2$ \\
\hline Mean & & & & & $203 \pm 6$ & $387 \pm 177$ & $24.4 \pm 5.6$ & $9.4 \pm 2.8$ & $62.3 \pm 7.3$ & $25.5 \pm 8.3$ \\
\hline \multirow[t]{8}{*}{ Cassin's auklet } & & UB2008 & 5 & 2008 & 182 & 213 & 24.8 & $13.7 \pm 4.8$ & 101.3 & $60.7 \pm 18.6$ \\
\hline & M & 03901 & 5 & 2009 & nd & 194 & 12.8 & $5.6 \pm 2.4$ & 72.0 & $25.2 \pm 16.6$ \\
\hline & $\mathrm{F}$ & 03902 & 3 & 2009 & nd & 304 & 23.5 & $7.4 \pm 4.5$ & 102.7 & $30.5 \pm 24.7$ \\
\hline & $\mathrm{F}$ & 03903 & 3 & 2009 & nd & 413 & 20.0 & $5.9 \pm 3.2$ & 83.2 & $17.4 \pm 15.7$ \\
\hline & $\mathrm{F}$ & 03904 & 5 & 2009 & nd & 328 & 22.8 & $5.9 \pm 3.8$ & 90.2 & $20.6 \pm 16.2$ \\
\hline & $\mathrm{M}$ & 03905 & 5 & 2009 & nd & 248 & 24.7 & $11.8 \pm 5.4$ & 84.6 & $45.2 \pm 20.6$ \\
\hline & $\mathrm{M}$ & 03906 & 5 & 2009 & nd & 156 & 25.4 & $14.3 \pm 5.1$ & 87.0 & $58.0 \pm 17.8$ \\
\hline & $\mathrm{M}$ & UB2009 & 5 & 2009 & 181 & 351 & 23.4 & $7.2 \pm 3.7$ & 83.0 & $31.3 \pm 16.7$ \\
\hline (E) & $\mathrm{F}$ & 03908 & 5 & 2009 & 182 & 347 & 23.3 & $7.8 \pm 4.0$ & 87.7 & $35.6 \pm 18.5$ \\
\hline (F) & $\mathrm{M}$ & 03912 & 5 & 2009 & 204 & 343 & 28.1 & $9.8 \pm 5.9$ & 97.5 & $40.9 \pm 21.2$ \\
\hline (E) & $\mathrm{M}$ & 03914 & 5 & 2009 & 185 & 375 & 17.3 & $6.3 \pm 2.9$ & 71.4 & $26.7 \pm 18.1$ \\
\hline (F) & $\mathrm{F}$ & 03918 & 3 & 2009 & 170 & 382 & 22.6 & $10.5 \pm 5.1$ & 88.5 & $39.9 \pm 20.5$ \\
\hline Mean & & & & & $184 \pm 11$ & $305 \pm 82$ & $22.4 \pm 4.0$ & $8.9 \pm 3.1$ & $87.4 \pm 9.9$ & $36.0 \pm 13.7$ \\
\hline
\end{tabular}

handled previously with no negative consequence and therefore are accustomed to handling; or (3) birds that are sensitive to handling do not return to the nest boxes. Similarly, $13 \%$ of non-previously banded thickbilled murres abandoned while $0 \%$ of previously banded birds deserted following attachment of monitoring devices (K. H. Elliott unpubl. data). As the corticosterone stress response decreases with age in seabirds, perhaps young, unbanded birds abandon because they have a stronger stress response to handling (Newman et al. 2005, K. H. Elliott unpubl. data).

Although our sample sizes for dummy treatment groups were small due to ethical considerations ( $\mathrm{n}=5$ to 6 per group), we suggest the following guidelines for attaching recording equipment to small alcids based on data provided in Table 1: (1) use previously banded birds or choose well-established parts of the colony to avoid encountering inexperienced birds; (2) attach devices to the leg (minimizes body drag, but alters balance) or back, as both methods cause statistically insignificant differences in desertion (back: $33 \%$ recapture rate for murrelets; leg: $48 \%$ ), but avoid use of surgery (surgery: $28 \%$ recapture rate averaged across Table 1; no surgery: $83 \%$ ); (3) attach the devices early in the day, as done in 2009, as this may allow stress to return to baseline before nightfall; (4) minimize disturbance to the bird and its partner, as done in 2009 (the partner may be able to compensate for disrupted behavior in the equipped bird, Paredes et al. 2005); (5) remove the bird from its burrow for easier handling (removal: $48 \%$ recapture rate for murrelets; nonremoval: $40 \%$ ); and (6) use chick-rearing birds, as they are less likely to abandon (incubation: $40 \%$ recapture rate averaged across Table 1 ; chick-rearing 95\%). Although at other locations females are less likely to abandon than males (Ackerman et al. 2004, Paredes et al. 2005), there was no sex bias in the birds we equipped successfully (we only sexed our birds upon return), suggesting that we had a similar desertion rate between the 2 sexes (Table 3 ).

Past studies have claimed that devices $<5 \%$ of body mass have 'minimal' impact on alcid behavior, based on either high return rates, mass loss 'typical' for that species or average chick growth rates (e.g. Croll et al. 1992, p. 348; cited over 20 times as evidence for the ' $<5 \%$ rule'). Some species, such as the small alcids we studied (especially Synthliboramphus, Newman et al. 2005), are very sensitive to handling and display negative impacts regardless of the size of the device (Table 1). Nonetheless, even in species with high within-year 

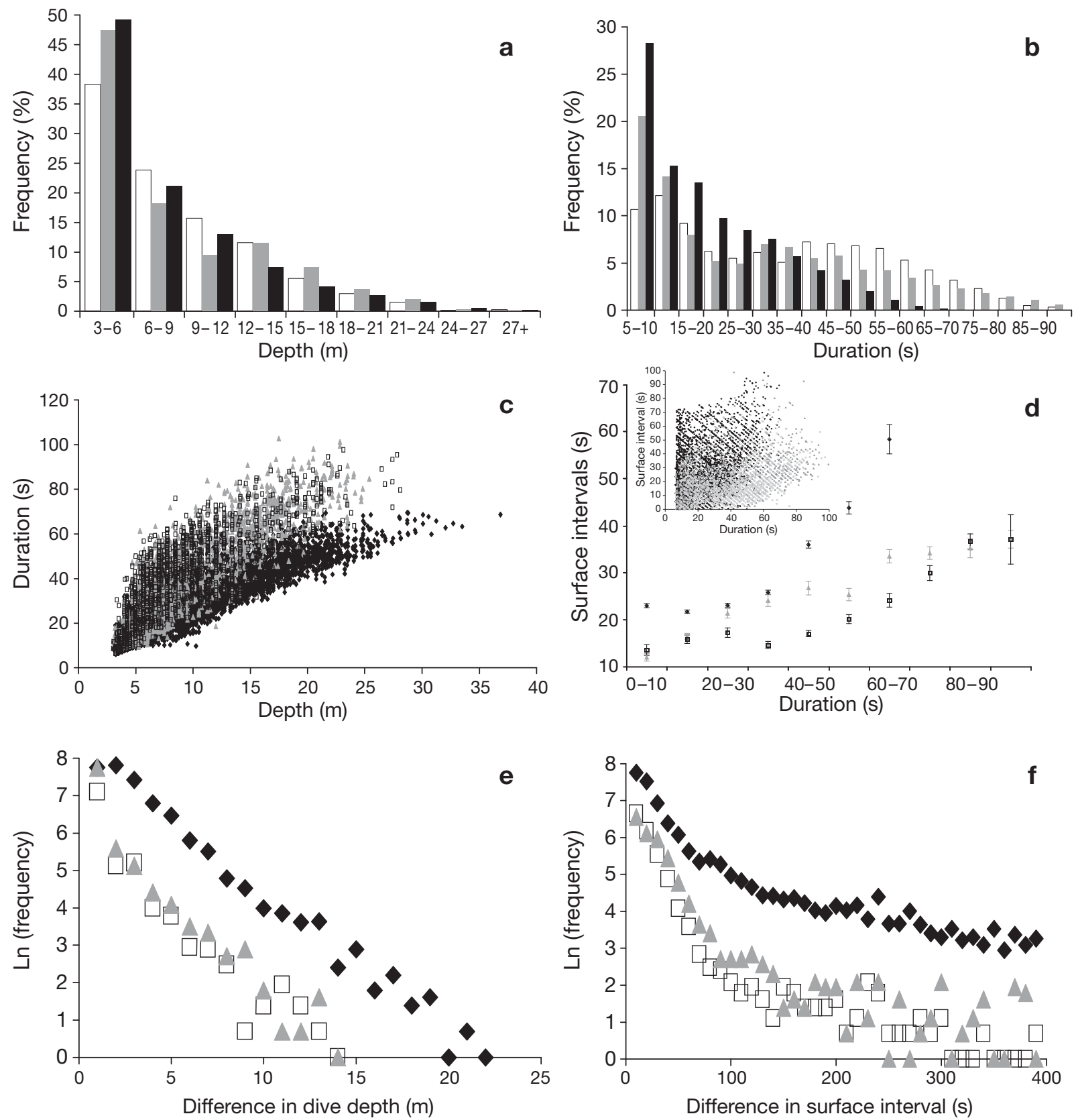

Fig. 1. Synthliboramphus antiquus and Ptychoramphus aleuticus. (a,b) Frequency histograms for depth and duration of dives, respectively. Cassin's auklets have (c) longer dive duration for a given depth and (d) shorter anticipatory surface pause intervals for a given depth compared with ancient murrelets. Both species showed bout structure following (e) a 1-process model for dive depth and (f) a 2-process model for surface intervals. White: Cassin's auklet (chick-rearing); grey: Cassin's auklet (incubating); black: ancient murrelet (incubating)

recapture rates and low mass loss, easy-to-obtain measures of device effects on the adults, such as mass loss, corticosterone concentration and device retrieval rates, may mask subtle attributes, including time spent feeding, dive behavior and at-sea activity, because of compensation by the mate or because the costs are passed on to the chick (Paredes et al. 2005, Elliott et al. 2007, 2008a, Takahashi et al. 2008). Consequently, devices as low as $1 \%$ of body mass may well be impacting measurements of the very parameters they are trying to measure (Table 1), although it is sometimes unclear whether the effects are due to the devices or to handling. We suggest that researchers strive for devices $<1 \%$ of body mass for alcids, while acknowledging that all devices are likely to impact behavior, in accordance with the uncertainty principle of wildlife biology. 
Table 4. Comparison of flying and diving behavior of ancient murrelets and Cassin's aukets with other alcids

\begin{tabular}{|c|c|c|c|c|c|c|c|}
\hline Species & $\begin{array}{l}\text { Time spent } \\
\text { flying }(\%)\end{array}$ & $\begin{array}{l}\text { Flights } \\
\left(\text { no. } d^{-1}\right)\end{array}$ & $\begin{array}{l}\text { Time spent } \\
\text { diving (\%) }\end{array}$ & $\begin{array}{l}\text { Dive } \\
\text { shape }\end{array}$ & $\begin{array}{l}\text { No. } \\
\text { dives }\end{array}$ & $\begin{array}{l}\text { Max. depth } \\
\text { (m) }\end{array}$ & Source \\
\hline Ancient murrelet & 10.0 & 21 & 11.4 & $\mathrm{~V}$ & 387 & 24 & Present study \\
\hline Cassin's auklet & 8.1 & 29 & 12.7 & $\mathrm{~V}, \mathrm{~W}$ & 305 & 22 & Present study \\
\hline Dovekie & & & 10.6 & $\mathrm{~V}$ & 184 & 21 & Harding et al. (2009) \\
\hline Rhinoceros auklet & & & 17.0 & $\mathrm{~V}, \mathrm{~W}$ & 261 & 50 & Kuroki et al. (2003) \\
\hline \multirow[t]{2}{*}{ Razorbill } & & & 2.8 & $\mathrm{~V}, \mathrm{~W}$ & 49 & 36 & Paredes et al. (2008) \\
\hline & 13 & & 6.5 & $\mathrm{~V}$ & 427 & 41 & Dall'Antonia et al. (2001) \\
\hline \multirow[t]{3}{*}{ Common murre } & 3.5 & & 17.1 & & & & Monaghan et al. (1994) \\
\hline & 1.4 & & 7.7 & & & & Monaghan et al. (1994) \\
\hline & 11.0 & & 14.6 & & & & Cairns et al. (1990) \\
\hline \multirow[t]{4}{*}{ Thick-billed murre } & 4.6 & 5 & 12.6 & $\mathrm{~V}, \mathrm{U}$ & 160 & 88 & Elliott et al. (2007) \\
\hline & 7.6 & & 16.3 & $\mathrm{~V}, \mathrm{U}$ & & & Falk et al. (2002) \\
\hline & 5.2 & & 11.2 & $\mathrm{~V}, \mathrm{U}$ & & & Falk et al. (2002) \\
\hline & & & 6.4 & W, U & 51 & 110 & Paredes et al. (2008) \\
\hline
\end{tabular}

Physiological parameters, $\mathrm{O}_{2}$ stores and aerobic dive limits

When our values were combined with values obtained from the literature, myoglobin concentration increased with body mass in aquatic but not terrestrial animals (Lindstedt \& Thomas 1994; Fig. 5c). Buffering capacity increased with body mass $\left(t_{16}=2.69, \mathrm{p}=0.02\right)$ and myoglobin levels (Fig. 5d) in aquatic but not terrestrial (myoglobin: Fig. 5d; mass: $t_{8}=0.40, \mathrm{p}=0.71$ ) animals. After excluding pinnipeds, which have several adaptations for high blood hemoglobin levels while submerged, blood hemoglobin concentrations decreased with mass in aquatic birds and mammals

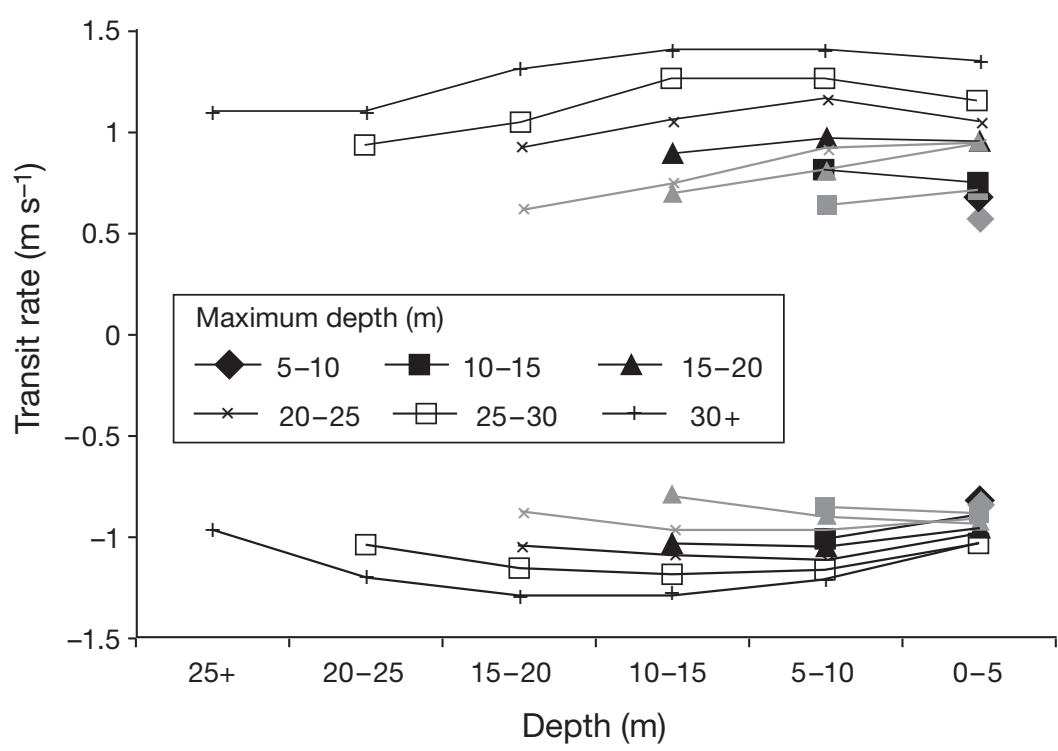

Fig. 2. Synthliboramphus antiquus and Ptychoramphus aleuticus. Ascent (positive values) and descent (negative values) rates for ancient murrelets (black symols and lines) and Cassin's auklets (grey symols and lines) at different maximum depths. Error bars excluded for clarity. This analysis includes only depths $5 \mathrm{~m}$ above maximum depth achieved, and only continuous descents and ascents (no reverses in direction)
(Fig. 5b). Marine homeotherms have higher hematocrit, blood hemoglobin and muscle myoglobin content and proton buffering capacity than semi-aquatic homeotherms, which have higher values than terrestrial animals, reflecting the large $\mathrm{O}_{2}$ stores needed for breath-hold diving (Fig. 5). Similarly, compared to a non-diving charadriiform bird, hematocrit, hemoglobin content and proton buffering capacity was relatively high in both diving auklets (Table 2).

The relatively low myoglobin concentrations found within the skeletal muscles of the 2 small planktivores compared to other vertebrate divers (Fig. 5c) is surprising given the importance of this $\mathrm{O}_{2}$ reservoir for underwater endurance (Kooyman \& Ponganis 1998). Our values were slightly lower than those reported for the pectoralis of other diving alcids (Davis \& Guderly 1987, Haggblom et al. 1988, Croll et al. 1992, Enoki \& Morimoto 2000), which may have arisen because our breast samples included both supracoracoideus and pectoralis muscle. The high levels of mitochondrial enzymes needed to support high mass-specific metabolic rates (and the corresponding reduction in space available for myoglobin) may underlie the lower myoglobin concentrations $\left(10 \mathrm{~g} \mathrm{~kg}^{-1}\right)$ found within the flight muscles of the $\sim 200 \mathrm{~g}$ planktivorous small alcids compared to those in $980 \mathrm{~g}$ murres (14 $\mathrm{g} \mathrm{kg}^{-1}$ ) and $30000 \mathrm{~g}$ penguins (64 g kg ${ }^{-1}$, Kooyman \& Ponganis 1998). A similar explanation could apply to the notably lower skeletal muscle myogloblin concentrations found in starnosed moles and muskrats (14 $\mathrm{g} \mathrm{kg}^{-1}$; MacArthur et al. 2001, McIntyre et al. 2002) compared to larger-bodied divers 

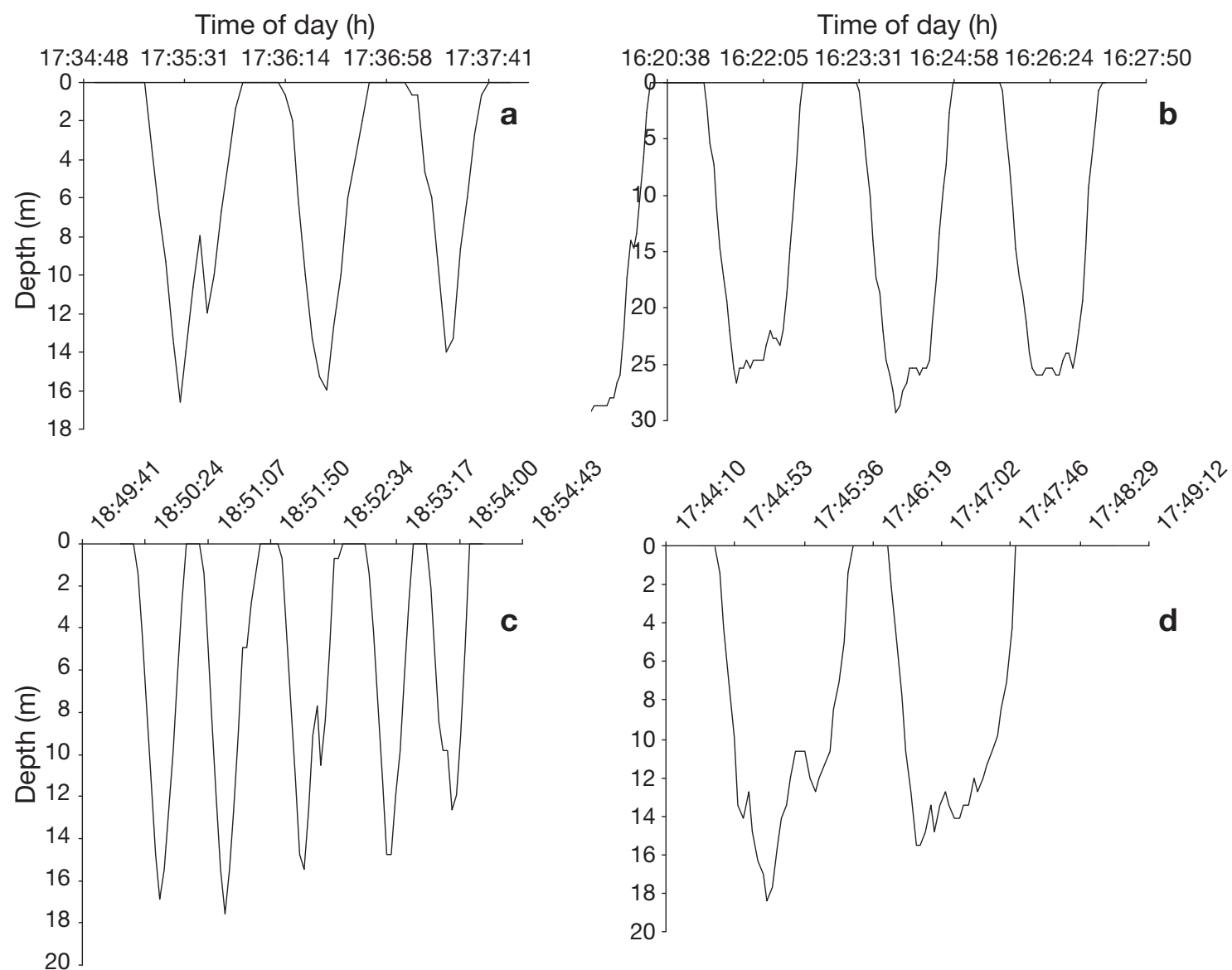

Fig. 3. Synthliboramphus antiquus and Ptychoramphus aleuticus. Typical dive profiles for (a) incubating ancient murrelets and (b) incubating and chick-rearing Cassin's auklets that subsequently provisioned with (c) fish and (d) krill. Note differences in axis scales

( $60 \mathrm{~g} \mathrm{~kg}^{-1}$ for large toothed whales; Fig. 5c). Conversely, the relatively low myoglobin concentrations found in flying divers (alcids) may instead simply reflect the relatively high mitochondrial volumes needed to support flight (Davis \& Guderly 1987, Croll et al. 1992), thus limiting the amount of myoglobin that can be maintained in flight muscle. Because alcid flight muscle is primarily composed of Type I fibers, and Type I fibers have higher myoglobin concentrations than Type II fibers (Ordway \& Garry 2004), fiber type cannot explain why alcids have low myoglobin relative to other divers.

Whereas large marine animals, such as pinnipeds and large penguins, have a large proportion of their $\mathrm{O}_{2}$ stores in their muscle, small birds and mammals do not appear to have this option (Fig. 6). Instead, the majority of $\mathrm{O}_{2}$ stores are located in the respiratory system and blood (Fig. 6, Table 2), which may lead to increased selective pressure to improve blood $\mathrm{O}_{2}$ storage and, consequently, high blood hemoglobin concentrations in small aquatic birds and mammals (Fig. $5 b)$. Whether a given small diving species increases blood or respiratory $\mathrm{O}_{2}$ stores may depend on the depth to which it dives. Shallow-diving ducks have relatively high respiratory $\mathrm{O}_{2}$ stores, while deep-diving alcids have relatively high blood $\mathrm{O}_{2}$ stores, possibly because any further increase in respiratory stores would greatly increase buoyancy-related costs when diving to depth (Fig. 6). The high buffering capacity of skeletal muscle in the 2 small alcids (20 to $30 \%$ higher than the non-diver; Table 2) is interesting given that buffering capacity increases with body mass in diving mammals because larger animals have higher protein (myoglobin) concentrations (Fig. 5c) and, therefore, may be expected to have a greater number of titratable histidine residues per unit muscle mass. Buffering capacity is also primarily associated with Type II fibers (Hochachka \& Mommsen 1983, Nakagawa \& Hattori 2002, Abe 2000), so fiber type also cannot explain the discrepancy. Adequate intracellular buffers are critical to ensure optimum $\mathrm{pH}$ for glycolysis, the only process of ATP generation in diving animals once $\mathrm{O}_{2}$ stores are exhausted. Allometric scaling of glycolytic enzymes to mass predicts that small alcids should have a poor abil- 


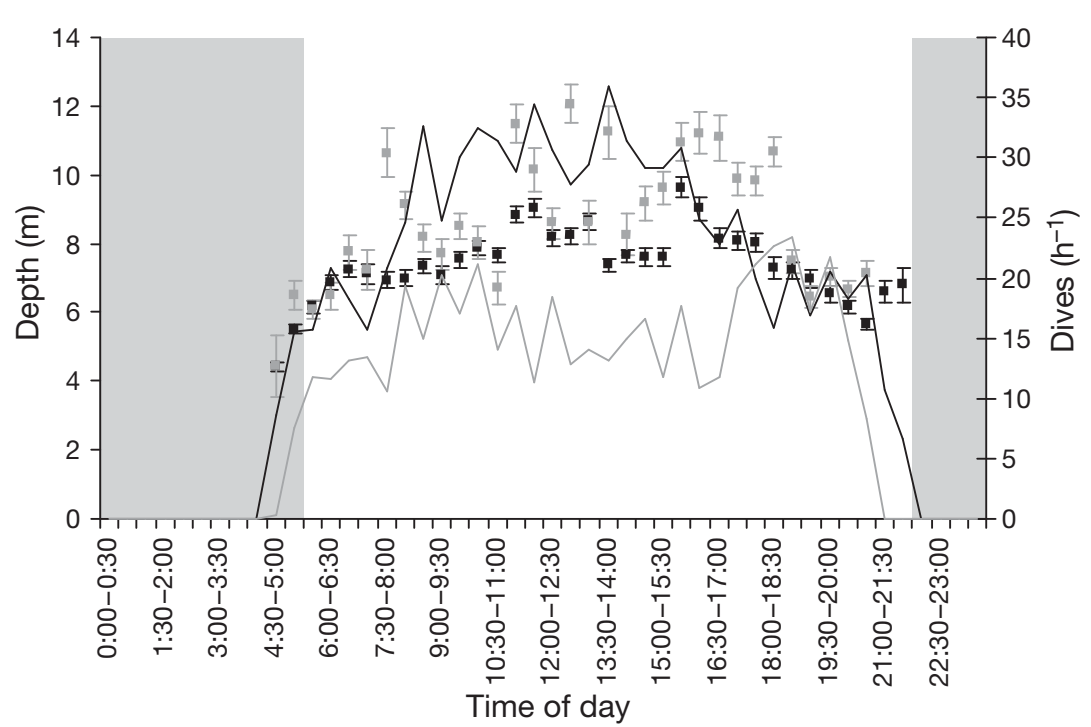

Fig. 4. Synthliboramphus antiquus and Ptychoramphus aleuticus. Dive depth (squares $\pm \mathrm{SE}$ ) and dives per hour (lines) for ancient murrelets (black) and Cassin's auklets (grey). Note that both variables are highest during midday

ity to utilize glycolysis (Emmett \& Hochachka 1981), and a high buffering capacity (more histidines per protein molecule) may be one way in which alcids can enhance glycolysis to extend dives.

Using total $\mathrm{O}_{2}$ stores shown in Table 2, assuming a metabolic scaling factor of 0.73 and using a diving metabolic rate of $0.93 \mathrm{ml} \mathrm{s}^{-1} \mathrm{~kg}^{-1}$ for murres in a shallow dive tank $(\sim 3 \times$ basal metabolic rate, Croll et al. 1992, Croll \& McLaren 1993), we calculated an aerobic dive limit (ADL) of $39.6 \mathrm{~s}$ for murrelets and $39.4 \mathrm{~s}$ for auklets. Similar values ( 39 s) are obtained if we convert the total $\mathrm{O}_{2}$ stores of auklets $(10.4 \mathrm{ml})$ and murrelets (11.8 ml) into work (assuming $20.1 \mathrm{~J} \mathrm{ml} \mathrm{O}_{2}^{-1}$ ) and consider the depth achieved $(\sim 9 \mathrm{~m})$ if the birds are to descend and ascend on $220 \mathrm{~J}$ of aerobic work (Lovvorn 2010, this Theme Section). A depth of $10 \mathrm{~m}$ is equivalent to about $39 \mathrm{~s}$ (see Fig. 1).

In total, $44 \%$ of chick-rearing auklet dives, $36 \%$ of incubating auklet dives and $13 \%$ of murrelet dives exceeded their estimated ADLs (39 s). Many dives by both murrelets and auklets exceeded their respective calculated ADLs ( 39 s). It is unlikely that these small alcids actually routinely exceed their ADL because the surface pause to dive duration relationship for both species (Fig. 1) was weak (cf. Elliott et al. 2008b) and anticipatory, implying that they do not routinely metabolize high levels of lactate at the surface. The calculated ADLs of avian divers are often underestimated (Kooyman \& Ponganis 1998, Knower Stockard et al. 2005, Ponganis et al. 2010, this Theme Section). A possible reason for the discrepancy in our case is that diving metabolic rates of free-ranging murres, as measured using doubly labeled water, is less than half the value measured in shallow tanks (which we used to estimate ADLs), likely because low buoyancy costs and enhanced vasomotor responses reduce metabolic rate during deep dives (Niizuma et al. 2007, K. H. Elliott unpubl. data). A 2-fold reduction of the estimated diving metabolic rate would lead to an ADL of $\sim 78 \mathrm{~s}$; few dives for either species exceeded this value. However, alcids engaging in pelagic dives exhibit high activity throughout the dive (Elliott et al. 2009b), so pelagic-diving auklets and murrelets may not show the same degree of reduction in diving metabolic rate as benthic-diving murres; the true ADL of auklets and/or murrelets probably lies somewhere between 39 and $78 \mathrm{~s}$. Experiments measuring $\mathrm{O}_{2}$ consumption rates and lactate levels for small alcids during diving are sorely needed to resolve this issue, and we use the ADL only as a crude measure for comparing dive behavior.

\section{Foraging behavior}

Auklets dove for longer than murrelets, while murrelets dove deeper, meaning that auklets were submerged for $60 \%$ longer than murrelets at any given dive depth. Descent rates of both species increased with depth, in accordance with a concurrent reduction in buoyancy (greater acceleration for a constant work per stroke, Lovvorn et al. 1999, 2004), then decreased as the bird approached maximum depth and started searching for prey. Ascent rates decreased with depth, as birds employed buoyancy to return to the surface, and increased with maximum depth, as deep diving birds likely descended with greater air stores and were more buoyant (Sato et al. 2002, Elliott et al. 2007). Descent rates were less variable than ascent rates, possibly because descent rates were maximized to occur in a narrow wingbeat frequency while ascent rates reflected variations in buoyancy. As is the case for murres (Croll et al. 1992, Hedd et al. 2009), and is generally more common in birds than mammals (Kooyman \& Ponganis 1998), a high proportion of dives (auklets: 30 to $40 \%$; murrelets: $13 \%$ ) exceeded their respective estimated ADLs. Higher mass-specific $\mathrm{O}_{2}$ stores, proton buffering capacity and dive durations for a given surface interval for auklets suggest that auklets are more regularly limited than murrelets by $\mathrm{O}_{2}$ stores due to the longer dive durations of auklets. There was little difference in shape, depth or duration between individual dives of incubating versus chick-rearing auklets. However, chick-rearing birds spent much more time under- 

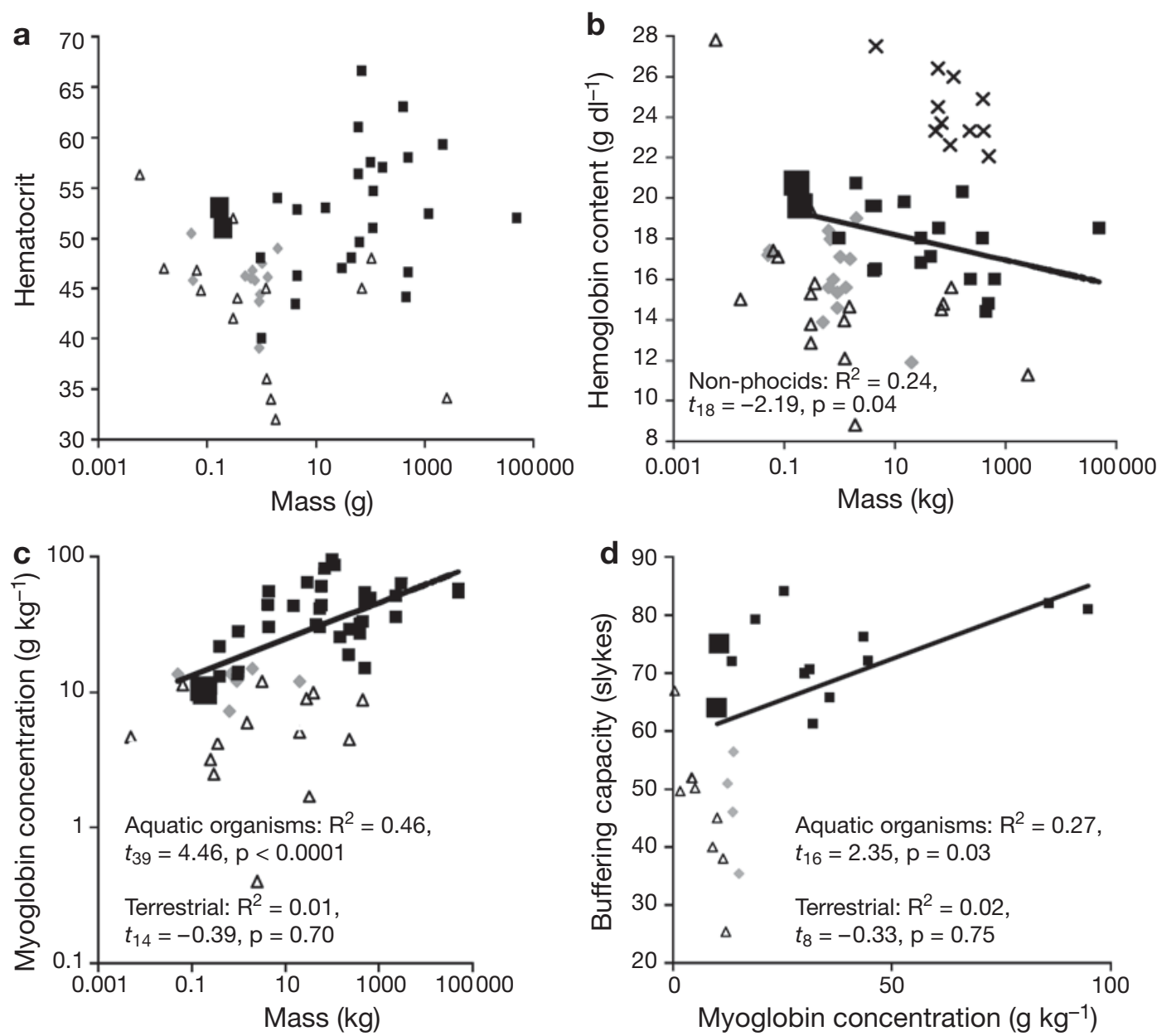

Fig. 5. Synthliboramphus antiquus and Ptychoramphus aleuticus. (a) Hematocrit, (b) hemoglobin content, (c) myoglobin concentration and (d) proton buffering capacity for semi-aquatic $(\diamond)$, marine $(\boldsymbol{\square})$ and terrestrial $(\Delta)$ organisms (x: seals, for blood parameters). Regressions are shown for (b) all non-phocid aquatic animals and (c) all aquatic organisms. The large squares represent the 2 small alcids in Table 2. Sources are shown in Table S3 in the Supplement (see www.int-res.com/articles/suppl/b008p221_ app.xls)

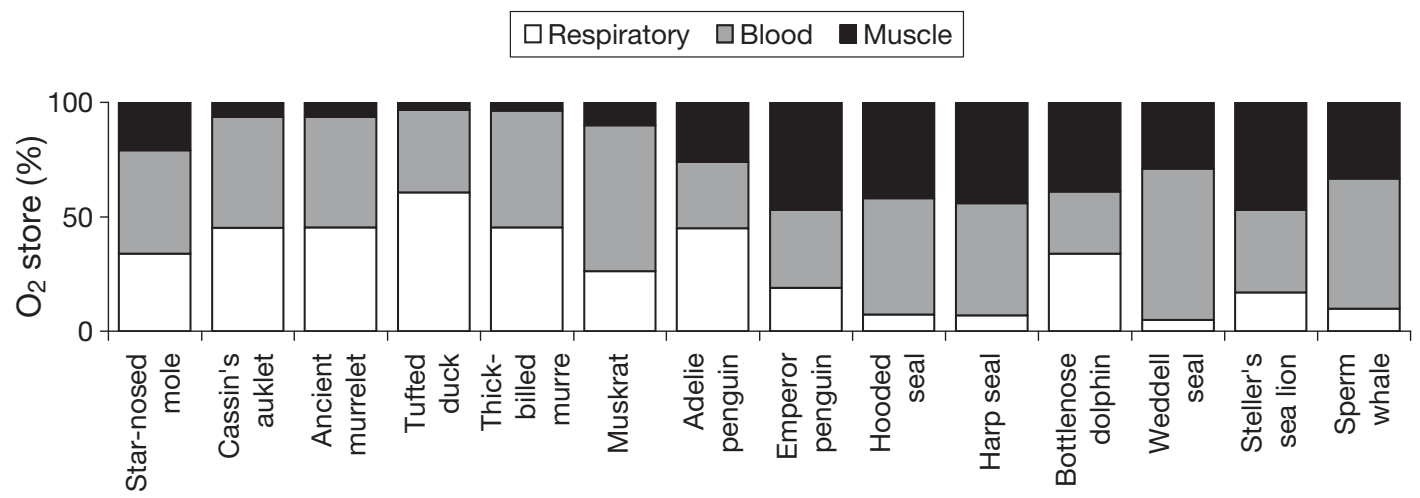

Fig. 6. Oxygen store distribution for a variety of vertebrates

water (dove more frequently, not longer) due to the greater energy demands of chick-rearing.

Neither species dove at night, with diving starting $1 \mathrm{~h}$ before sunrise and ending $1 \mathrm{~h}$ after sunset (Fig. 4). For auklets, which visited the colony nightly, the absence of night diving might be accounted for by time at the colony. However, most murrelets spent at least 1 night away from the colony during TDTR deployments, hence the absence of night diving presumably relates to limited nocturnal feeding opportunities. Maximum possible radii was $66 \mathrm{~km} \mathrm{~d}^{-1}$ for murrelets and $53 \mathrm{~km} \mathrm{~d}^{-1}$ for auklets; however, as flying was broken into bouts (Table 4), 
the maximum distance traveled from the colony was likely much less (Elliott et al. 2009a, Thaxter et al. 2009).

The differences in foraging behavior between auklets and murrelets either represents different foraging tactics for capturing the same prey or differences in prey type, as foraging behavior indicates prey type in other alcids (Elliott et al. 2008a). The dive depths and durations of auklets and murrelets were comparable to those of $150 \mathrm{~g}$ planktivorous dovekies Alle alle, while dive shape was comparable between dovekies and murrelets (Harding et al. 2009, Table 4). Dive depths and durations were much smaller than for larger-bodied alcids, but total time spent underwater was similar, due to the greater number of dives by the smaller alcids (Table 4). The V-shaped dives of murrelets were also very similar to those associated with other alcids feeding on small fish (Table 4), while the W-shaped dives of auklets were comparable to those associated with Spheniscus penguins feeding on schooling krill or other prey (Simeone \& Wilson 2003, Takahashi et al. 2004). Auklets provisioning with fish tended to have deeper, V-shaped dives than those provisioning with krill (Fig. 3), and murrelets in Haida Gwaii tended to feed themselves with more fish than auklets (Vermeer et al. 1985), suggesting that the V-shaped dives may be associated with fish and the $\mathrm{W}$-shaped dives with krill. In Haida Gwaii, auklet stomach contents contained $42 \%$ copepods, $39 \%$ crustacean larvae and $13 \%$ krill, while auklet chicks were provisioned with krill and fish (likely sandlance; see also Burger \& Powell 1990). Murrelet stomach contents at Haida Gwaii contained $56 \%$ krill and $44 \%$ fish during mid incubation and $99 \%$ fish during late incubation (all of our TDR measurements were in late incubation; Vermeer et al. 1985). Thus dietary information from Haida Gwaii supports the idea that V-shaped dives are used to capture fish (self-feeding, incubating murrelets and auklets provisioning with fish) and $\mathrm{W}$-shaped dives are used to capture invertebrates (self-feeding, incubating auklets and auklets provisioning with krill). To conclude, 2 species of sympatric auklet partitioned their small fish/ plankton niche by using different foraging strategies, possibly because they were feeding on different components of the niche (krill vs. fish), and each component was caught in a different manner.

Acknowledgements. We thank G. Martin, L. McKnightYeates, C. Pansino, J. Pattison and Laskeek Bay Conservation Society for their hospitality in Haida Gwaii. C. Eberl provided excellent logistic help. M. Yoneda and K. Woo were able and thoughtful assistants. J. Provencher identified auklet prey samples. D. Crump sexed the birds. Environment Canada funded the field component of the study, while laboratory components were funded from a Natural Sciences and Engineering Research Council (NSERC) Discovery Grant to K.L.C.

\section{LITERATURE CITED}

Abraham CL, Sydeman WJ (2006) Prey-switching by Cassin's auklets Ptychoramphus aleuticus reveals seasonal climaterelated cycles of Euphausia pacifica and Thysanoessa spinifera. Mar Ecol Prog Ser 313:271-283

Ackerman JT, Adams J, Takekawa JY, Carter HR and others (2004) Effects of radiotransmitters on the reproductive performance of Cassin's auklets. Wildl Soc Bull 32:1229-1241

Bailleul F, Luque S, Dubroca L, Arnould JPY, Guinet C (2005) Differences in foraging strategy and maternal behaviour between two sympatric fur seal species at the Crozet Islands. Mar Ecol Prog Ser 293:273-282

> Burger AE, Powell DW (1990) Diving depths and diet of Cassin's auklet at Reef Island, British Columbia. Can J Zool 68:1572-1577

Cairns DK, Montevecchi WA, Birt-Friesen VL, Macko SA (1990) Energy expenditures, activity budgets and prey harvest of breeding common murres. Stud Avian Biol 14: $84-92$

Castellini MA, Somero GN (1981) Buffering capacity of vertebrate muscle: correlations with potentials for anaerobic function. J Comp Physiol B 143:191-198

Croll DA, McLaren E (1993) Diving metabolism and thermoregulation in common and thick-billed murres. J Comp Physiol B 163:160-166

Croll DA, Gaston AJ, Burger AE, Konnoff D (1992) Foraging behavior and physiological adaptation for diving in thickbilled murres. Ecology 73:344-356

> Dall'Antonia L, Gudmundsson GA, Benvenuti S (2001) Time allocation and foraging pattern of chick-rearing razorbills in northwest Iceland. Condor 103:469-480

Davis MB, Guderly H (1987) Energy metabolism in the locomotor muscles of the common murre (Uria aalge) and the Atlantic puffin (Fratercula arctica). Auk 104:733-739

- Elliott KH, Gaston AJ (2009) Accuracy of depth recorders. Waterbirds 32:183-191

> Elliott KH, Hewett M, Kaiser GW, Blake RW (2004) Flight energetics of the marbled murrelet Brachyramphus marmoratus. Can J Zool 82:644-652

> Elliott KH, Davoren GK, Gaston AJ (2007) The influence of buoyancy and drag on the dive behaviour of an Arctic seabird, the thick-billed murre. Can J Zool 85:352-361

Elliott KH, Woo K, Gaston AJ, Benvenuti S, Dall'Antonia L, Davoren GK (2008a) Seabird foraging behaviour indicates prey type. Mar Ecol Prog Ser 354:289-303

Elliott KH, Davoren GK, Gaston AJ (2008b) Time allocation by a deep-diving bird reflects prey type and energy gain. Anim Behav 75:1301-1310

Elliott KH, Bull RD, Gaston AJ, Davoren GK (2009a) Underwater and above-water search patterns of an Arctic seabird: reduced searching at small spatiotemporal scales. Behav Ecol Sociobiol 63:1773-1785

> Elliott KH, Woo KJ, Benvenuti S (2009b) Do activity costs determine foraging tactics for an arctic seabird? Mar Biol 156:1809-1816

- Emmett B, Hochachka PW (1981) Scaling of oxidative and glycolytic enzymes in mammals. Respir Physiol 45:261-272

> Enoki Y, Morimoto T (2000) Gizzard myoglobin contents and feeding habits in avian species. Comp Biochem Physiol 125:33-43

Falk K, Benvenuti S, Dall'Antonia L, Gilchrist G, Kampp K (2002) Foraging behaviour of thick-billed murres breeding in different sectors of the North Water polynya: an intercolony comparison. Mar Ecol Prog Ser 231:293-302

Felsenstein J (1989) PHYLIP — Phylogeny Inference Package (Version 3.2). Cladistics 5:164-166 
Grant BR, Grant PR (2002) Lack of premating isolation at the base of a phylogenetic tree. Am Nat 160:1-19

Haggblom L, Terwilliger RC, Terwilliger NB (1988) Changes in myoglobin and lactate dehydrogenase in muscle tissues of a diving bird, the pigeon guillemot, during maturation. Comp Biochem Physiol 91:237-277

Halsey LG, Butler PJ, Blackburn TM (2006) A phylogenetic analysis of the allometry of diving. Am Nat 167:276-287

Hamel NJ, Parrish JK, Conquest LL (2004) Effects of tagging on behaviour, provisioning, and reproduction in the common murre (Uria aalge), a diving seabird. Auk 121: $1161-1171$

Harding AMA, Egevang C, Walkusz W, Merkel F, Blanc S, Grémillet D (2009) Estimating prey capture rates of a planktivorous seabird, the little auk (Alle alle), using diet, diving behaviour, and energy consumption. Polar Biol 32:785-796

Hatch SA, Meyers PM, Mulcahy DM, Douglas DC (2000) Performance of implantable satellite transmitters in diving seabirds. Waterbirds 23:84-94

> Hedd A, Regular PM, Montevecchi WA, Buren AD, Burke CM, Fifield DA (2009) Going deep: common murres dive into frigid water for aggregated, persistent and slowmoving capelin. Mar Biol 156:741-751

Hipfner JM (2008) Matches and mismatches: ocean climate, prey phenology and breeding success in a zooplanktivorous seabird. Mar Ecol Prog Ser 368:295-304

Hochachka PW, Mommsen TP (1983) Protons and anaerobiosis. Science 219:1391-1397

Hull CL (1999) The foraging zones of breeding royal (Eudyptes schlegeli) and rockhopper (E. chrysocome) penguins: an assessment of techniques and species comparison. Wildl Res 26:789-803

Hunt GL Jr, Russell RW, Coyle KO, Weingartner T (1998) Comparative foraging ecology of planktivorous auklets in relation to ocean physics and prey availability. Mar Ecol Prog Ser 167:241-259

Jodice PGR, Collopy MW (1999) Diving and foraging patterns of Marbled Murrelets (Brachyamphus marmoratus): testing predictions from optimal-breathing models. Can J Zool 77:1409-1418

Knower Stockard T, Heil J, Meir JU, Sato K, Ponganis KV, Ponganis PJ (2005) Air sac $P_{\mathrm{O} 2}$ and oxygen depletion during dives of emperor penguins. J Exp Biol 208:2973-2980

Lasiewski RC, Calder WA (1971) A preliminary allometric analysis of respiratory variables in resting birds. Respir Physiol 11:152-166

Lindstedt SL, Thomas RG (1994) Exercise performance of mammals: an allometric perspective. Adv Vet Sci Comp Med 38:191-217

> Lovvorn JR (2010) Modeling profitability for the smallest marine endotherms: auklets foraging within pelagic prey patches. Aquat Biol 8:203-219

Lovvorn JR, Croll DA, Liggins GA (1999) Mechanical versus physiological determinants of swimming speeds in diving Brünnich's guillemots. J Exp Biol 207:4679-4695

Lovvorn JR, Watanuki Y, Kato A, Naito Y, Liggins GA (2004) Stroke patterns and regulation of swim speed and energy cost in free-ranging Brünnich's guillemots. J Exp Biol 207: 4679-4695

Luque SP, Arnould JPY, Miller EH, Cherel Y, Guinet C (2007) Foraging behaviour of sympatric Antarctic and subantarctic fur seals: Does their contrasting duration of lactation make a difference? Mar Biol 152:213-224

> MacArthur RA, Humphries MM, Fines GA, Campbell KL (2001) Body oxygen stores, aerobic dive limits, and the diving abilities of juvenile and adult muskrats (Ondatra zibethicus). Physiol Biochem Zool 74:178-190
McIntyre IW, Campbell KL, MacArthur RA (2002) Body oxygen stores, aerobic dive limits and diving behaviour of the star-nosed mole (Condylura cristata) and comparisons with non-aquatic talpids. J Exp Biol 205:45-54

> Meyers PM, Hatch SA, Mulcahy DM (1998) Effect of implanted satellite transmitters on the nesting behavior of murres. Condor 100:172-174

Monaghan P, Walton P, Wanless S, Uttley JD, Burns MD (1994) Effects of prey abundance on the foraging behavior, diving efficiency and time allocation of breeding guillemots Uria aalge. Ibis 136:214-222

> Mori Y, Boyd IL (2004) Segregation of foraging between two sympatric penguin species: Does rate maximization make the difference? Mar Ecol Prog Ser 275:241-249

Mori Y, Yoda K, Sato K (2001) Defining dive bouts using a sequential differences analysis. Behaviour 138:1451-1466

Nakagawa Y, Hattori M (2002) Relationship between muscle buffering capacity and fiber type during anaerobic exercise in human. J Physiol Anthropol 21:129-131

Newman SH, Takekawa JY, Whitworth DL, Burkett EE (1999) Anchor attachment increases retention of radio transmitters on Xantus' and marbled murrelets. J Field Ornithol 70:520-534

Newman SH, Carter HR, Whitworth DL, Zinkl JG (2005) Health assessments and stress response of Xantus's murrelets to capture, handling and radio-marking. Mar Ornithol 33:147-154

Niizuma Y, Gabrielsen GW, Sato K, Watanuki Y, Naito Y (2007) Brünnich's guillemots (Uria lomvia) maintain high temperatures in the body core during dives. Comp Biochem Physiol A 147:438-444

> Noren SR, Williams TM (2000) Body size and skeletal muscle myoglobin of cetaceans: adaptations for maximizing dive duration. Comp Biochem Physiol A 126:181-191

Ordway GA, Garry DJ (2004) Myoglobin: an essential hemoprotein in striated muscle. J Exp Biol 207:3441-3446

Paredes R, Jones IL, Boness DJ (2005) Reduced parental care, compensatory behaviour and reproductive costs experienced by female and male thick-billed murres equipped with data loggers. Anim Behav 69:197-208

Paredes R, Jones IL, Boness DJ, Tremblay Y, Renner M (2008) Sex-specific differences in diving behaviour of two sympatric Alcini species: thick-billed murres and razorbills. Can J Zool 86:610-622

Ponganis PJ, Costello ML, Starke LN, Mathieu-Costello O, Kooyman GL (1997) Structural and biochemical characteristics of locomotory muscles of emperor penguins, Aptenodytes fosteri. Respir Physiol 109:73-80

> Ponganis PJ, Stockard T, Meir JU, Williams CL, Ponganis KV, Howard $\mathrm{R}$ (2009) $\mathrm{O}_{2}$ store management in diving emperor penguins. J Exp Biol 212:217-224

> Ponganis PJ, Meir JU, Williams CL (2010) Oxygen store depletion and the aerobic dive limit in empror penguins. Aquat Biol 8:237-245

Quinlan SE, Hughes JH (1992) Techniques for capture and radio tagging of marbled murrelets. In: Carter HR, Morrison ML (eds) Status and conservation of the marbled murrelet in North America. Proc West Found Vertebr Zool, 5:117-121

Reynafarje B (1963) Simplified method for the determination of myoglobin. J Lab Clin Med 61:138-145

Sato K, Naito Y, Kato A, Niizuma Y and others (2002) Buoyancy and maximal diving depth in penguins: Do they control inhaling air volume? J Exp Biol 205:1189-1197

Sealy SG (1975) Feeding ecology of the ancient and marbled murrelet near Langara Island, British Columbia. Can J Zool 53:418-433 
Simeone A, Wilson RP (2003) In-depth studies of Magellanic penguin (Spheniscus magellanicus) foraging: Can we estimate prey consumption by perturbations in the dive profile? Mar Biol 143:825-831

Takahashi A, Dunn MJ, Trathan PN, Croxall JP, Wilson RP, Sato K, Naito Y (2004) Krill-feeding behaviour in a chinstrap penguin Pygoscelis antarctica compared with fisheating in Magellanic penguins Spheniscus magellanicus: a pilot study. Mar Ornithol 32:47-54

Takahashi A, Matsumoto K, Hunt GL, Shultz MT and others (2008) Thick-billed murres use different diving behaviors in mixed and stratified waters. Deep-Sea Res II 55:1837-1845

Thaxter CB, Daunt F, Hamer KC, Watanuki Y and others (2009) Sex-specific food provisioning in a monomorphic seabird, the common guillemot Uria aalge: nest defence, foraging efficiency or foraging effort? J Avian Biol 40: 75-84

Tremblay Y, Cherel Y, Oremus M, Tveraa T, Chastel O (2003) Unconventional ventral attachment of time-depth recorders as a new method for investigating time budget and diving behaviour of seabirds. J Exp Biol 206:1929-1940

Trivelpiece WZ, Trivelpiece SG, Volkman NJ (1987) Ecological segregation of Adelie, gentoo and chinstrap penguins

Submitted: August 5, 2009; Accepted: February 17, 2010 at King George Island, Antarctica. Ecology 68:351-361

> Vermeer K, Fulton JD, Sealy SG (1985) Differential use of zooplankton prey by ancient murrelets and Cassin's auklets in the Queen Charlotte Islands. J Plankton Res 7:443-459

Wanless S, Harris MP, Morris JA (1985) Radio-monitoring as a method for estimating time budgets of guillemots (Uria aalge). Bird Study 32:170-175

Wanless S, Morris JA, Harris MP (1988) Diving behaviour of guillemot Uria aalge, puffin Fratercula arctica and razorbill Alca torda as shown by radio-telemetry. J Zool 216: 73-81

Watanuki Y, Burger AE (1999) Body mass and dive duration in alcids and penguins. Can J Zool 77:1838-1842

- Watanuki Y, Mehlum F, Takahashi A (2001) Water temperature sampling by foraging Brünnich's guillemots with bird-borne data loggers. J Avian Biol 32:189-193

Whidden SE, Williams CT, Breton AR, Buck CL (2007) Effects of transmitters on the reproductive success of tufted puffins. J Field Ornithol 78:206-212

Wolf SG, Sydeman WJ, Hipfner JM, Abraham CL, Tershy BR, Croll DA (2009) Range-wide reproductive consequences of ocean climate variability for the seabird Cassin's auklet. Ecology 90:742-753

Proofs received from author(s): March 10, 2010 